\title{
Prospek Kebutuhan Layanan Psikologis Untuk Atlet Jaya Raya
}

\author{
Soerjoatmodjo, G.W.L. ${ }^{1}$, Kaihatu, V.A.M. ${ }^{2}$, Moningka, C. ${ }^{3}$, Angkawijaya, Y.F. ${ }^{4}$ \\ ${ }_{1,2,3,4}$ Program Studi Psikologi, Universitas Pembangunan Jaya \\ gita.soerjoatmodjo@upj.ac.id
}

\begin{abstract}
After 40 years, Jaya Raya as one of the most progressive badminton clubs in the country, sets up the first Badminton School in Indonesia for 80, 1218-year-old male and female single and double athletes. Key issue faced by Jaya Raya is the need to produce champions and to do so, psychological services are needed. This writing aims to capture psychological services prospects of Jaya Raya athletes. Rapid Assessment Process approach is used in this action research that applies semi-structured interview, focus group discussion and workshop analyzed through triangulation. Results show that the existing needs include pedagogy and understanding adolescence; psychological skills such as goal setting, mental imagery and self-talk, profiles; assessment and counselling as well as human resource management in the organizational level. This research concludes that there is a prospect for psychological services in physical and technical coaches, teachers and boarding school officer.
\end{abstract}

Keywords : Sport Psychology, Need Assessment, Action Research, Psychological Services, Badminton

\begin{abstract}
Abstrak : Setelah berdiri 40 tahun, Jaya Raya sebagai salah satu klub bulutangkis terdepan mendirikan Sekolah Bulutangkis pertama di Indonesia yang membina 80 atlet usia 12-18 tahun cabang tunggal putra, tunggal putri, ganda putra, ganda putri dan ganda campuran. Permasalahan Jaya Raya adalah kebutuhan menelurkan juara bulutangkis dimana upaya tersebut membutuhkan layanan psikologis. Tujuan penelitian ini adalah memotret prospek kebutuhan layanan atlet Jaya Raya. Dengan pendekatan Rapid Assessment Process, penelitian aksi ini mengumpulkan data dari wawancara, diskusi kelompok dan workshop yang dianalisis menggunakan triangulasi. Hasil penelitian ini menunjukkan kebutuhan akan pengetahuan pedagogi dan perkembangan remaja; keterampilan psikologis seperti goal setting, mental imagery dan self-talk; profil, instrumen alat ukur dan konseling serta manajemen sumber daya manusia di tingkat organisasi. Kesimpulan penelitian adalah ada prospek layanan psikologis pada pelatih teknik, pelatih fisik, guru, pengurus asrama maupun Jaya Raya sendiri sebagai organisasi. Kata Kunci : Psikologi Olahraga, Pengukuran Kebutuhan, Penelitian Aksi, Layanan Psikologis, Bulutangkis
\end{abstract}

\section{PENDAHULUAN \\ Latar Belakang}

Untuk pertama kali dalam sejarah, Indonesia memiliki Sekolah Bulutangkis yaitu Gedung Olah Raga (GOR) Jaya Raya di Bintaro Jaya (Netralnews, 2016). Berdiri 15 September 2016, Jaya Raya memiliki bangunan seluas 4.583 meter persegi, lahan 1.3 hektar, 16 lapangan dan tribun berkapasitas 500 penonton. Jaya Raya juga dilengkapi sekolah setingkat
SMP dan SMA dengan menggunakan Kurikulum 2013 dan dilengkapi dengan asrama. Semua ini dimanfaatkan oleh para atlet yang dibina Jaya Raya. Terdapat minimal 80 atlet Jaya Raya laki-laki dan perempuan usia 12-18 tahun yang saat ini ditangani oleh pelatih fisik, pelatih teknik, guru dan pengurus asrama selama 4 hari dalam seminggu dari pagi hingga malam.

Di usianya ke-40, Jaya Raya menjadi salah satu klub bulutangkis 
terdepan di Indonesia. Hal ini tercermin dari prestasi yang disumbangkan oleh atlet Jaya Raya untuk Indonesia yaitu 3 medali emas Olimpiade, 8 medali emas Asian Games dan 59 medali emas SEA Games, 8 gelar juara Kejuaraan Dunia, 12 juara All England, 13 juara beregu dan perseorangan Kejuaran Asia, 8 Piala Thomas, 3 Piala Uber dan 1 Piala Sudirman (Wondowisnowo, 2016).

Seiring komitmen Jaya Raya, muncul kebutuhan akan layanan psikologi. Hal ini karena pendiri Ir. Ciputra menegaskan keinginannya agar atlet Jaya Raya kembali membawa medali emas untuk Indonesia (Detik, 2016). Prestasi terakhir adalah mengalahkan Djarum Kudus dalam Pembangunan Jaya Cup VI 17 Desember 2016 (Tempo, 2016). Kemenangan ini dianggap menebus kekalahan Jaya Raya 3-0 dari Djarum Kudus di Kejuaraan Nasional PBSI (Persatuan Bulutangkis Seluruh Indonesia) 10 Desember 2016 (Jawapos, 2016).

Aspirasi menghasilkan atlet berprestasi masuk dalam ranah keilmuan psikologi olahraga. Psikologi olahraga bertujuan mengidentifikasi faktor psikologis yang mempengaruhi partisipasi dan performa individu di bidang olahraga serta intervensi peningkatan prestasi dan pengembangan pribadi (Williams \& Straub, 2010).

Salah satu bentuk penerapan psikologi olahraga adalah penguasaan keterampilan psikologis. Keterampilan psikologis (psychological skills) merupakan perilaku hasil belajar untuk dimanfaatkan atlet agar berprestasi, antara lain kepercayaan diri, motivasi (Anderson, Mahoney, Miles \& Robinson, 2002). Sayangnya, masalah bidang psikologi olahraga ini antara lain keterbatasan sumber daya manusia terutama dalam pembinaan (Hoedaya, 2007). Demi efektivitas dan efisiensi, penting melakukan pengukuran kebutuhan (need assessment) Jaya Raya agar dapat digunakan sebagai acuan.

\section{Pertanyaan Penelitian}

Pertanyaan penelitian ini adalah: layanan psikologis apa saja yang dibutuhkan oleh atlet Jaya Raya?

\section{Tujuan Penelitian}

Penelitian ini bertujuan mendapatkan gambaran kebutuhan atlet Jaya Raya akan layanan psikologis.

\section{Sistematika Penulisan}

Penelitian ini terdiri dari pendahuluan, latar belakang, metodologi, hasil penelitian dan analisis, kesimpulan dan daftar pustaka

\section{KAJIAN PUSTAKA}

Bulutangkis adalah olahraga menggunakan raket yang dimainkan 2 orang (cabang tunggal) atau 2 pasangan (cabang ganda) saling berlawanan.

Tujuan olahraga ini adalah memukul shuttlecock lewat jaring agar jatuh di bidang permainan lawan yang ditentukan seraya mencegah lawan melakukan hal serupa (Asfiyani \& Sulistyarto, 2016).

Atlet bulutangkis sendiri, menurut Putri (2016) dikategorisasikan berdasarkan gender, usia dan cabang. Pembagian atlet berdasarkan usia tercermin pada Tabel 1 di bawah ini.

Tabel 1. Atlet Bulutangkis Berdasarkan

\begin{tabular}{|c|c|}
\multicolumn{2}{c}{ Usia } \\
\hline Usia & Kategori \\
\hline 10 tahun ke bawah & Anak \\
\hline $\mathbf{1 0 - 1 3}$ tahun & Pemula \\
\hline $13-15$ tahun & Remaja \\
\hline $15-19$ tahun & Taruna \\
\hline 19 tahun ke atas & Dewasa \\
\hline
\end{tabular}

Para atlet tersebut berlaga dalam 5 cabang yakni (1) tunggal putra dan (2) putri, (3) ganda putra, dan (4) putri, serta (5) ganda campuran.

Atlet bulutangkis menjalani latihan demi mencapai kondisi fisik yang ditandai oleh volume oksigen pada paru-paru (Rana, 2012). Selain itu, atlet juga menjalani latihan teknik agar menguasai 
pukulan service, lob, dropshot, smash, backhand, drive sampai netting agar shuttlecock dapat diarahkan ke tempat yang sulit dijangkau dijangkau lawan (Putri, 2013).

Sementara program latihan terkonsentrasi pada pengembangan fisik dan teknik, keterampilan psikologis antara lain penetapan sasaran (goal setting), kemampuan berbicara pada diri sendiri (self-talk) dan imajeri mental (mental imagery) - justru masih terabaikan (Hidayat, 2016). Padahal mempersiapkan kondisi mental penting dalam olahraga. Gunarsa (2008) berpendapat bahwa tidak tertutup kemungkinan bahwa faktor mental menjadi penentu dalam pertandingan.

Terkait dengan hal di atas, penting untuk melakukan pengukuran kebutuhan (need assessment). Need assessment adalah proses membandingkan antara kondisi saat ini dengan kondisi yang diharapkan, mendefinisikan masalah, memahami perilaku dan mekanisme yang berkontribusi pada kondisi saat ini, menentukan apakah perilaku maupun mekanisme tertentu dapat diubah serta cara melakukan hal tersebut guna menghasilkan kondisi yang diharapkan, mengembangkan strategi untuk solusi dan membangun dukungan (Sleezer, Russ-Eft \& Gupta, 2014).

Dengan need assessment, penelitian ini diharapkan menghasilkan gambaran tentang prospek layanan psikologis yang dibutuhkan Jaya Raya. Langkah-langkah mencapai tujuan tersebut dapat dilihat di bagian berikut ini.

\section{METODE PENELITIAN}

Penelitian ini berbasis pada adanya keinginan memberdayakan subyek, dalam hal ini atlet Jaya Raya, sehingga mereka dapat mengambil manfaat sebesarbesarnya dari hasil penelitian- ketimbang mendudukkan mereka sebagai subyek pasif dalam eksperimen terkontrol. Oleh karena itu, jenis penelitian yang paling tepat menjawab hal ini adalah penelitian aksi (action research). Giles (2008) menjelaskan bahwa salah satu dari sederetan tujuan penelitian bidang psikologi adalah menghasilkan perubahan perilaku pada subyek, hanya saja action research secara khusus meletakkan perubahan tersebut sebagai sasaran eksplisit dibandingkan sebatas produk sampingan (by-product) dari sebuah kajian. Maka dapat disimpulkan bahwa penelitian ini tergolong sebagai penelitian action research.

Taylor (1994 dalam Giles, 2008) menjelaskan bahwa salah satu tipe action research adalah need assessment dimana kepentingan subyek untuk mendapatkan manfaat dari penelitian inilah yang menjadi fokus penelitian. Salah satu pendekatan dalam need assessment adalah proses pengukuran cepat (Rapid Assessment Process/RAP), yaitu penggalian informasi kualitatif secara intensif dan berbasis pada tim menggunakan triangulasi, analisis data secara iteratif dan pengumpulan data tambahan untuk secara cepat membangun pemahaman dasar tentang satu situasi dari sudut pandang pelaku (Beebe, 2001). Tujuan RAP adalah berbicara bebas dan terbuka dengan orang-orang yang terlibat agar mereka dapat menyampaikan pandangan mereka. RAP dapat digunakan dalam berbagai situasi yang membutuhkan penggalian informasi dengan pendekatan kualitatif, namun waktu dan sumber daya yang ada tak memungkinkan kerja lapangan jangka panjang. Maka dapat disimpulkan bahwa penelitian action research ini termasuk dalam tipe need assessment dengan pendekatan RAP.

Karena penelitian ini fokus pada upaya mendapatkan gambaran tentang layanan psikologis, dengan fokus pemberdayaan subyek, maka penelitian ini menggunakan metode kualitatif. Brown (2007) berpendapat bahwa dibandingkan dengan metode kuantitatif, metode kualitatif (qualitative method) meletakkan perhatian pada deskripsi akan konteks dimana peristiwa alamiah terjadi. Metode kualitatif justru unggul untuk mendapatkan 
potret deskriptif yang bisa jadi lensa bagi peneliti untuk memahami fenomena, dibanding semata-mata mengandalkan angka seperti skor tes.

Data yang dikumpulkan dalam penelitian ini bersifat primer dan sekunder. Data sekunder dilakukan melalui kajian literatur sedangkan data primer diambil menggunakan wawancara semi-terstruktur (semi-structured interview), focus group discussion dan workshop dengan para narasumber, dirangkum sebagai berikut.

Tabel 2. Pengumpulan Data (Data

$$
\text { Collection) }
$$

\begin{tabular}{|l|l|} 
Data & Teknik Pengumpulan Data \\
\hline \multirow{2}{*}{ Primer } & Semi-Structured Interview \\
\cline { 2 - 2 } & Focus Group Discussion \\
\cline { 2 - 2 } & Workshop \\
\hline \multirow{2}{*}{ Sekunder } & Kajian Literatur \\
\hline
\end{tabular}

Setelah data terkumpul, maka data dianalisis dengan cara triangulasi (triangulation). Silverman dalam Capobianco \& Feldman (2009) mendefinisikan triangulasi sebagai membandingkan berbagai jenis data dan berbagai jenis metode untuk melihat apakah data dan metode tersebut saling menguatkan (to corroborate) antara satu sama lain. Elliot dalam Capobianco \& Feldman (2009) menguatkan dengan berpendapat bahwa prinsip dasar triangulasi adalah bahwa data dikumpulkan dalam satu situasi dari berbagai sudut pandang atau perspektif sehingga dalam ditarik persamaan maupun perbedaannya. Maka dapat disimpulkan bahwa penelitian ini menggunakan triangulasi sebagai metode analisis.

Adapun penelitian ini dilakukan dalam langkah-langkah berikut. Tahap pertama adalah mengidenfikasi pemangku kepentingan (stakeholders). Hal ini dilakukan dengan mengkaji rekaman diskusi antara pihak Universitas Pembangunan Jaya dan pihak Jaya Raya (Program Studi Psikologi Universitas Pembangunan Jaya, 2016). Dalam kesempatan ini, pihak-pihak yang menjadi narasumber adalah pihak dari Universitas Pembangunan Jaya yaitu jajaran rektorat dan Program Studi Psikologi, jajaran pimpinan Jaya Raya seperti Direktur Ekskutif dan Ketua Harian, penasihat serta pelatih fisik dan teknik, juga jajaran Kelompok Usaha Pembangunan Jaya antara lain pendiri, direktur eksekutif dan jajaran direksi. Kajian ini memunculkan pihak-pihak yang relevan terhadap identifikasi prospek layanan psikologis Jaya Raya yakni atlet, pelatih fisik, pelatih teknik, guru dan pengurus asrama.

Berikutnya adalah melakukan kajian literatur. Tahap kedua adalah melakukan kajian literatur tentang psikologi olahraga dari berbagai sumber. Tahap ketiga adalah melakukan hal serupa pada Jaya Raya dari media massa. Hal ini untuk memetakan kekuatan Jaya Raya serta mengetahui hal-hal apa saja yang perlu ditingkatkan. Tahap keempat adalah mengkaji skripsi Putri (2016) tentang atlet Jaya Raya dan berdiskusi dengan para dosen pembimbing skripsi guna mendapatkan hikmah (insights) selama proses penyusunan skripsi. Tahap ini dilengkapi dengan upaya mengkaji kembali rekaman proses mata kuliah Psikologi Olahraga tahun 2013/2014 dimana skripsi Putri (2016) menjadi kelanjutan dari tugas mata kuliah ini. Tahap kedua sampai keempat dilakukan sepanjang bulan Desember 2016.

Tahap kelima adalah melakukan diskusi dengan psikolog olahraga yang berkiprah di bulutangkis yakni Amran Effendi Siregar, S.Pd., M.Si., (dilakukan pada tanggal 4 Januari 2017 di Jakarta) dan Lilik Sudarwati, S.Psi., M.H. (dilakukan pada tanggal 5 Januari 2017 di Jakarta). Selain mengidentifikasi layanan psikologis apa saja yang pernah terlaksana di cabang olahraga ini, diskusi ini bertujuan untuk mencari bentuk layanan psikologis yang tepat untuk tingkat klub seperti Jaya Raya.

Tahap keenam adalah melakukan diskusi kelompok dengan 12 orang tim Jaya Raya yang mewakili pihak sekolah, 
pengurus asrama, pelatih teknik dan pelatih fisik. Sedangkan Tim Program Studi Psikologi Universitas Pembangunan Jaya terdiri dari 4 orang dengan latar belakang Psikologi Pendidikan, Intervensi Sosial, Psikologi Sosial dan Psikologi Industri dan Organisasi. Hal-hal yang digali dalam kesempatan ini adalah untuk mendapatkan gambaran kebutuhan mereka sebagai pihak-pihak yang berperan membina atlet Jaya Raya meraih prestasi, Dalam menjalankan tugas tersebut, kebutuhan akan layanan psikologis apa saja yang mereka pikirkan dan rasakan. Hal tersebut dianalisa dari hasil wawancara yang menggali tentang proses di tubuh Jaya Raya sebagai sebuah organisasi, mulai dari rekrutmen sampai terminasi.

Tahap selanjutnya adalah melakukan wawancara dengan Prof. Danu Hoedaya, Ph.D, profesor Psikologi Olahraga dari Universitas Pendidikan Indonesia (UPI) yang juga Ketua Bidang Psikologi Olahraga Komite Olahraga Nasional Indonesia Jawa Barat (KONI Jabar) di Gedung KONI Jabar 26 Januari 2017. Wawancara ini dilakukan bersamasama dengan Dra. Ardanti Ratna Widyastuti, M.Si. selaku Wakil Ketua di waktu dan tempat yang sama. Selain itu, dilakukan juga wawancara di Fakultas Pendidikan Olahraga dan Kesehatan UPI dengan Dr. Yusup Hidayat, S.Pd, M.Si. yang menyelesaikan disertasi doktoral dari Fakultas Psikologi Universitas Gadjah Mada bertajuk Intervensi Psikologis Strategi Multi-Teknik terhadap Hasil Belajar Keterampilan Dasar Bermain Bulutangkis, Motivasi Olahraga dan Kepercayaan Diri.

Wawancara pada tahap ini dilakukan untuk melengkapi hal serupa yang dilakukan pada tahap sebelumnya, yakni mengidentifikasi layanan psikologis apa saja yang pernah terlaksana di cabang olahraga ini, diskusi ini bertujuan untuk mencari bentuk layanan psikologis yang tepat untuk tingkat klub seperti Jaya Raya
Transkripsi wawancara dan diskusi kelompok dilengkapi catatan proses dianalisa untuk mengidentifikasi kebutuhan layanan psikologis Jaya Raya.

Tahap akhir adalah melakukan penggalian pada atlet Jaya Raya itu sendiri. Hal ini dilakukan dalam workshop perkenalan dengan 80 atlet di Bintaro pada tanggal 8 Februari 2017. Di dalam kegiatan diskusi kelompok, mereka mengungkapkan apa yang mereka ketahui tentang psikologi secara umum dan psikologi olahraga secara khusus, motivasi mereka memilih bulutangkis secara umum dan menjadi atlet secara khusus, serta gambaran kondisi psikologis mereka saat berlatih, bertanding serta saat mengalami kemenangan dan, sebaliknya, kekalahan. Jawaban-jawaban tersebut dianalisa lebih jauh untuk mendapatkan gambaran kebutuhan akan layanan psikologis.

Tabel 3. Data Penelitian dan Narasumber

\begin{tabular}{l|l}
\multicolumn{1}{c}{$\begin{array}{c}\text { Teknik } \\
\text { Pengumpulan } \\
\text { Data }\end{array}$} & \multicolumn{1}{c}{ Narasumber } \\
\hline $\begin{array}{l}\text { Semi- } \\
\text { Structured } \\
\text { Interview }\end{array}$ & $\begin{array}{l}\text { Praktisi dan akademisi } \\
\text { psikologi olahraga; dan } \\
\text { perwakilan PBSI serta KONI }\end{array}$ \\
\hline $\begin{array}{l}\text { Focus Group } \\
\text { Discussion }\end{array}$ & $\begin{array}{l}\text { Jajaran Kelompok Usaha } \\
\text { Pembangunan Jaya, Jaya } \\
\text { Raya, Universitas } \\
\text { Pembangunan Jaya; dan } \\
\text { pelatih fisik, pelatih teknik, } \\
\text { guru dan pengurus asrama } \\
\text { Jaya Raya }\end{array}$ \\
\hline Workshop & $\begin{array}{l}\text { Atlet Jaya Raya cabang } \\
\text { tunggal dan ganda putra putri } \\
\text { dan campuran }\end{array}$ \\
\hline $\begin{array}{l}\text { Kajian } \\
\text { Literatur }\end{array}$ & $\begin{array}{l}\text { Skripsi, Thesis, Disertasi, } \\
\text { Jurnal }\end{array}$ \\
\hline
\end{tabular}

Adapun hasil dari langkahlangkah tersebut di atas diuraikan dalam bagian berikut ini.

\section{HASIL PENELITIAN DAN ANALISIS}

Hasil penelitian ini disarikan dari rangkaian wawancara dari sejumlah 
narasumber sebagaimana diuraikan pada bagian Metodologi, dan telah melalui proses triangulasi.

Psikologi, khususnya psikologi olahraga memiliki aplikasi yang sensitif terhadap konteks (context-sensitive). Oleh karena itu, penguasaan teknis tentang cabang olahraga, termasuk pola latihan dan pertandingannya. penting untuk dikuasai oleh psikolog dan/atau ahli psikologi. Pada cabang olahraga bulutangkis, selain atlet itu sendiri, maka pemangku kepentingan (stakeholders) atau pihak yang berperan sebagai penjaga pintu (gate keeper) adalah pelatih fisik dan pelatih teknik yang sehari-hari berinteraksi dengan atlet.

Khusus untuk Jaya Raya, berbeda dengan klub-klub lain di Indonesia, klub ini tidak hanya memiliki pelatih fisik maupun teknik tetapi juga guru serta pengurus asrama. Pihak-pihak tersebutlah yang peran penting akibat adanya interaksi dan kedekatan (proximity) yang tinggi dalam keseharian atlet. Konteks tersebut di atas amat sangat unik pada Jaya Raya dan menjadi kekuatan pembeda Jaya Raya dengan klub-klub bulutangkis lainnya di Indonesia.

Terkait dengan pelatih, juga guru dan pengurus asrama, sebagian merasakan kebutuhan untuk mengetahui profil atlet (profiling) - misalnya gambaran tentang motivasi internal dan eksternal, gaya belajar yang cocok, aspirasi masa depan, cara mereka membuat keputusan (decision making), cara mereka mengatasi masalah (problem solving), cara mereka mengatasi stres (coping) serta strategi penyesuaian diri (adjustment) dan lain sebagainya.

Pengetahuan tentang hal-hal tersebut di atas diperlukan demi memastikan agar latihan fisik dan teknik di lapangan maupun proses belajar mengajar di kelas berlangsung efektif dan efisien sesuai dengan profil atlet.

Sebagian pelatih teknik, pelatih fisik, guru dan pengurus asrama merasakan kebutuhan peningkatan kapasitas (capacity building) dalam penyusunan program integratif fisik, teknik dan psikologis.

Khusus untuk keterampilan psikologis (psychological skills) seperti goal setting, mental imagery dan self-talk, sebagian dari pihak-pihak di atas belum memiliki pengetahuan apalagi kompetensi untuk mengembangkan keterampilan ini pada atlet.

Dari segi organisasi, terdapat kebutuhan pada Jaya Raya untuk memahami dan menguasai manajemen sumber daya manusia/SDM (human resource management). Hal ini mengingat atlet, sekalipun berada di rentang usia remaja, sejatinya dapat disetarakan selayaknya karyawan yang bekerja untuk klub sebagai sebuah organisasi dengan cara mengejar prestasi sebanyakbanyaknya di tiap pertandingan. Meminjam bahasa organisasi, maka pelatih fisik, pelatih teknik, guru maupun pengurus asrama dapat diposisikan sebagai mentor maupun atasan dari para atlet yang notabene karyawan.

Oleh karena itu, penting bagi Jaya Raya sebagai organisasi untuk memahami dan menjalankan sistem manajemen SDM sebagaimana layaknya organisasi seperti rekrutmen (recruitment) yang mempertimbangkan rekam jejak (curriculum vitae) sebelumnya serta diperkuat dengan tes maupun wawancara baik dengan atlet dan keluarga.

Selain itu, perlu juga adanya penyusunan kontrak yang melibatkan atlet dan keluarga agar memastikan bahwa dukungan keluarga pada anak-anak mereka yang berprofesi sebagai atlet menjadi konstruktif dan terintegrasi. Hal ini juga dapat meminimalkan potensi konflik maupun kesalahan komunikasi antara orang tua dengan pelatih. Penataran (onboarding) baik untuk atlet maupun keluarga menjadi penting agar semua pihak mendapatkan gambaran besar (big picture) dari keseluruhan proses yang berlangsung di Jaya Raya.

Penting juga untuk menguasai isu seperti seleksi dan penempatan (selection 
and placement) terutama untuk memilih dan menempatkan atlet pada cabang yang sesuai. Selain itu, penting juga bagi Jaya Raya untuk menyusun sistem penimbangan kinerja (performance appraisal) yang meliputi latihan dan pertandingan dengan sistem yang terukur dan transparan; dimana indikator yang sama digunakan untuk menentukan promosi (promotion) berupa penyertaan atlet pada kompetisi yang semakin lama semakin bergengsi; termasuk nantinya sampai ke proses terminasi (termination) dimana atlet dapat didegradasi atau keluar dari Jaya Raya untuk kembali ke klub satelit dan diasuh kembali oleh keluarga masing-masing karena dipandang tidak berprestasi.

Yang juga penting untuk dipahami dan dikuasai baik oleh pelatih, guru dan pengurus asrama adalah prinsip modifikasi perilaku (behaviour modification) seperti penggunaan ganjaran dan hukuman (reward and punishment) serta konsistensi serta panutan (role model) dari pelatih teknik, pelatih fisik, guru dan pengurus asrama dari segi aplikasi demi menumbuhkan disiplin.

Sebelum disiplin ini ditegakkan, dibutuhkan konsensus bersama antara pelatih fisik, pelatih teknik, guru dan pengurus asrama. Konsensus ini diperlukan untuk menyusun aturan main dan hal-hal yang boleh dan tidak boleh (dos and don'ts) secara bersama-sama. Konsensus inilah yang nantinya akan ditegakkan bersama-sama oleh pihakpihak tersebut di atas.

Hal tersebut di atas berresonansi juga oleh para atlet. Secara umum, atlet Jaya Raya memahami proses menjadi atlet khususnya di cabang olahraga bulutangkis membutuhkan komitmen. Selayaknya remaja yang menjalani transisi dari masa kanak-kanak ke dewasa, para atlet Jaya Raya mengungkapkan adanya kebutuhan akan dukungan sosial (social support) untuk menjalani komitmen tersebut.

Para atlet Jaya Raya membutuhkan dukungan sosial tersebut baik dari pelatih

teknik, pelatih fisik dan guru, sesama atlet dan terutama keluarga. Kebutuhan ini terutama dirasakan pada saat menghadapi tantangan dalam berlatih maupun bertanding, yang dijalani beriringan dengan proses penyesuaian diri menuju kedewasaan.

Proses menjadi juara yang dijalani bersama-sama dengan proses menjadi dewasa ini dirasa tidak mudah bagi para atlet- terutama saat menghadapi momen kekalahan.

Dukungan sosial yang mengadopsi prinsip modifikasi perilaku disertai pemahaman tugas perkembangan remaja tersebutlah yang perlu diterjemahkan ke dalam latihan di lapangan maupun pertandingan pada berbagai kompetisi maupun proses belajar mengajar di kelas. Kemampuan memberikan dukungan sosial ini dibutuhkan baik oleh pelatih fisik, pelatih teknik, guru maupun pengurus asrama.

Adapun temuan-temuan di atas dirangkum dalam tabel berikut ini:

\section{Stakeholders \\ Tabel}

\begin{tabular}{l}
\hline Atlet \\
\hline Pelatih \\
Teknik, \\
Pelatih \\
Fisik, Guru \\
dan
\end{tabular}

Pengurus

Asrama

Semua

\section{Kebutuhan Layanan} Psikologis

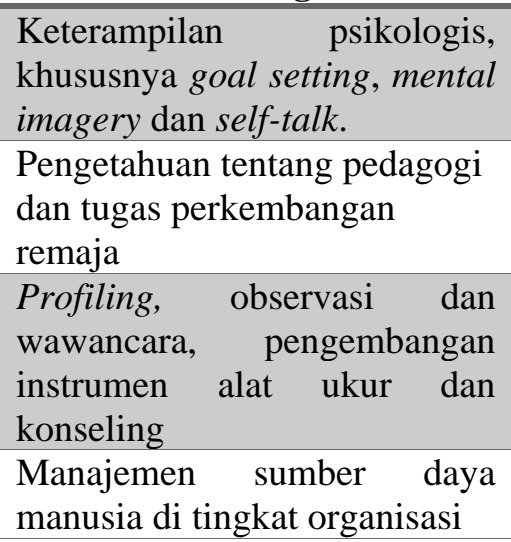

Sayangnya, kebutuhan-kebutuhan tersebut tampaknya tidak selalu diartikulasikan secara jelas. Keengganan pada sebagian pelatih antara lain akibat kurangnya rasa aman terhadap pekerjaannya (job security) serta isu tingginya beban kerja (work load) yang sangat terikat target dan waktu. 
Oleh karena itu, fokus sebagian pelatih menjadi terkonsentrasi pada penggunaan waktu sebesar-besarnya untuk mengejar target latihan agar atlet siap berkompetisi. Hal ini berdampak pada jadwal latihan yang ketat seraya jadwal pertandingan yang responsif.

Hal tersebut di atas juga berimplikasi pada bagaimana psikolog dan/atau ahli psikologi melakukan pengumpulkan data (data collection). Observasi dan wawancara atlet maupun pelatih yang berbasis pada hubungan yang hangat (rapport) menjadi teknik pengambilan data utama Tantangannya adalah melakukan itu semua di tengah keterbatasan waktu.

Keterbatasan waktu juga berdampak pada bagaimana sebagian psikolog dan/atau ahli psikologi mengandalkan asesmen (assessment) guna menghasilkan potret kilat. Mengingat instrumen alat ukur psikologi olahraga secara umum belum banyak dikembangkan, apalagi yang spesifik untuk bulutangkis, maka digunakanlah alat ukur psikologis standar seperti tes inteligensi dan kepribadian. Tak heran jika muncul isu-isu psikometri terkait antara lain tetapi tidak terbatas pada validitas, reliabilitas dan norma serta penyusunan psikogram.

Fokus pada asesmen juga berdampak bagaimana bidang ini dipersepsikan oleh sebagian psikolog dan/atau ahli psikologi. Praktik dalam industri asesmen adalah menghitung pendapatan berdasarkan jumlah individu yang menjalani proses asesmen. Jelas bahwa jumlah populasi atlet lebih sedikit dibandingkan misalnya dengan jumlah calon karyawan yang akan direkrut massal oleh sektor industri. Hal ini berdampak pada persepsi tentang prospek karir (career prospect) psikologi olahraga.

Isu lain adalah sebagian psikolog, khususnya dengan latar belakang Psikologi Klinis, menggunakan orientasi (orientation) non-psikologi positif. Pandangan ini melihat bahwa setiap individu serba bermasalah sehingga selalu perlu diintervensi untuk mengoreksi aneka kesalahan yang ada pada diri individu tersebut, antara lain melalui konseling (counselling).

Di satu sisi, benar bahwa konseling dibutuhkan untuk sebagian atlet terutama pada situasi menjelang maupun setelah pertandingan yang penuh tekananan, di sisi lain peningkatan kapasitas sebagian atlet terutama sepanjang proses latihan juga tak dapat ditinggalkan. Hal ini guna memastikan pencapaian performa puncak (peak performance) yang selaras dengan periodisasi latihan termasuk juga pemulihan (recovery).

Oleh karena itu, kebutuhan layanan psikologis menjadi jauh lebih besar pada tingkat klub yang melakukan pembinaan atlet alias di hulu. Jika diberikan pada tingkat nasional, atau dengan kata lain di hilir, tak banyak lagi yang dapat dilakukan.

Selain itu, terdapat komplikasi lain pada bidang olahraga di Indonesia pada tingkat nasional antara lain isu tentang bonus. Di satu sisi bonus dapat dipandang sebagai motivasi eksternal, di sisi lain, bonus terkait erat dengan tata kelola yang baik (good governance) dari organisasi olahraga yang perlu banyak dibenahi. Isu ini bukan semata di bidang bulutangkis tetapi berlaku secara umum di berbagai bidang olahraga di Indonesia.

Hal-hal tersebut di atas dapat dirangkum dalam Tabel 5 di bawah ini.

Tabel 5. Rangkuman Kebutuhan akan Layanan Psikologis dan Rekomendasi untuk Menjawab Kebutuhan

\begin{tabular}{l|l}
\multicolumn{1}{c}{ Kebutuhan } & \multicolumn{1}{c}{ Rekomendasi } \\
\hline $\begin{array}{l}\text { Pengetahuan } \\
\text { tentang pedagogi } \\
\text { dan perkembangan } \\
\text { remaja }\end{array}$ & $\begin{array}{l}\text { Psikoedukasi dan } \\
\text { capacity building } \\
\text { tentang modifikasi } \\
\text { perilaku pada remaja }\end{array}$ \\
\hline $\begin{array}{l}\text { Keterampilan } \\
\text { psikologis, } \\
\text { khususnya goal } \\
\text { setting, mental }\end{array}$ & $\begin{array}{l}\text { Capacity building } \\
\text { yang terintegrasi } \\
\text { dengan performance } \\
\text { appraisal }\end{array}$ \\
\hline
\end{tabular}




\begin{tabular}{l|l}
\hline $\begin{array}{l}\text { imagery dan self- } \\
\text { talk. }\end{array}$ & \\
\hline $\begin{array}{l}\text { Profiling, observasi } \\
\text { dan wawancara, } \\
\text { pengembangan } \\
\text { instrumen alat } \\
\text { ukur dan konseling }\end{array}$ & $\begin{array}{l}\text { Orientasi psikologi } \\
\text { positif }\end{array}$ \\
\hline $\begin{array}{l}\text { Manajemen } \\
\text { sumber daya } \\
\text { manusia di tingkat } \\
\text { organisasi }\end{array}$ & $\begin{array}{l}\text { Organizational } \\
\text { development } \\
\text { tingkat klub }\end{array}$ \\
\hline
\end{tabular}

\section{SIMPULAN}

Tulisan ini bertujuan menjawab pertanyaan akan gambaran kebutuhan atlet Jaya Raya akan layanan psikologis. Dengan pendekatan Rapid Assessment Process dengan metode pengumpulan data menggunakan wawancara, diskusi kelompok, workshop yang menghasilkan transkripsi, catatan observasi dan rekaman proses, maka dapat disimpulkan bahwa terdapat sejumlah kebutuhan akan layanan psikologis yang terdapat pada pelatih teknik, pelatih fisik, guru dan pengurus asrama.

Kebutuhan pertama adalah pengetahuan tentang pedagogi dan perkembangan remaja. Hal ini dapat dijawab dengan memberikan psikoedukasi dan peningkatan kapasitas dengan fokus pada modifikasi perilaku pada remaja.

Kebutuhan selanjutnya adalah pengetahuan tentang keterampilan psikologis. Keterampilan psikologis yang utama untuk atlet bulutangkis adalah goal setting, mental imagery dan self-talk. Rekomendasi untuk menjawab kebutuhan ini adalah melakukan peningkatan kapasitas. Peningkatan kapasitas ini direkomendasikan agar terintegrasi dengan penimbangan performa, misalnya grafik peningkatan kekuatan fisik, catatan penguasaan teknik dan evaluasi pembelajaran di sekolah.

Berikutnya, terdapat kebutuhan akan berbagai informasi untuk membuat proses berlatih dan bertanding menjadi efektif dan efisien. Kebutuhan informasi tersebut antara lain tetapi tidak terbatas pada profil, observasi dan wawancara, pengembangan instrumen alat ukur dan konseling.

Terakhir dan terpenting adalah bahwa Jaya Raya sebagai organisasi juga membutuhkan pengetahuan terkait dengan manajemen sumber daya manusia. Rekomendasi terkait dengan hal ini adalah pendampingan serta penguatan terutama untuk aspek pengembangan organisasi (organizational development).

\section{DAFTAR PUSTAKA}

1. Asfiyani, M.N \& Solistyarto, S., Analisis Pembinaan Cabang Olahraga Bulutangkis pada Klub Persatuan Bulutangkis Tri Darma di Kabupaten Tuban, Jurnal Kesehatan Olahraga Vol. 06 No. 2 Edisi Oktober, 2016, pp. 484-488.

2. Anderson, A.G., Mahoney, C., Miles, A. \& Robinson, P., Evaluating the Effectiveness of Applied Sport Psychology Practice: Making the Case of a Case Study Approach, The Sport Psychologist, 16, 2002, pp. 432453.

3. Beebe, J., Rapid Assessment Process: An Introduction Oxford: AltaMira Press, 2001.

4. Brown, D.S. Action Research and Educational Psychology. Praeger Handbook of Educaton and Psychology. Connecticut: Praeger, 2007.

5. Capobianco, B.M. \& Feldman, A. Promoting Quality for Teacher Action Research: Lessons Learned from Science Teachers' Action Research. Practical Action Research: A Collection of Articles. Richard A. Schmuck (editor) California: Corwin Press, 2009.

6. Detik, PB Jaya Raya: Prakarsa Ali Sadikin, Pernah Nyaris Tutup, Lahirkan Juara Olimpiade Diakses dari https://sport.detik.com/raket/d3301265/pb-jaya-raya-prakarsa-alisadikin-pernah-nyaris-tutup-lahirkanjuara-olimpiade tanggal 31 Januari 2017., 2016. 
7. Giles, D. Advanced Research Methods in Psychology New York: Routledge, 2008.

8. Gunarsa, S.D., Psikologi Olahraga Prestasi, Jakarta: PT BPK Gunung Mulia, 2008.

9. Hidayat, Y., Pengaruh Intervensi Psikologi Strategi Multi-Teknik Terhadap Hasil Belajar Keterampilan Dasar Bermain Bulutangkis, Motivasi Olahraga dan Kepercayaan Diri Disertasi S3 Fakultas Psikologi Universitas Gadjah Mada, 2016.

10. Hoedaya, D., Psikologi Olahraga: Tinjauan dari Perspektif Keilmuan dan Aplikasi dalam Olahraga Prestasi, Workshop Kajian Disiplin Keilmuan Olahraga. Jakarta: Komisi Nasional Pendidikan Jasmani dan Olahraga Kementerian Negara Pemuda dan Olahraga Republik Indonesia, 2007.

11. Jawapos, Akhiri Dominasi Jaya Raya, Djarum Kudus Kampiun Kejurnas PBSI, diakses dari http://www.jawapos.com/read/2016/1 2/10/69999/akhiri-dominasi-jayaraya-djarum-kudus-kampiun-kejurnaspbsi-2016 tanggal 31 Januari 2017.

12. Netralnews, PB Jaya Raya Dirikan Sekolah Bulutangkis Pertama di Indonesia diakses dari http://www.netralnews.com/news/olah raga/read/23843/pb.jaya.raya.dirikan.s ekolah.bulutangkis.pertama.di.indones ia.. tanggal 31 Januari 2017.

13. Program Studi Psikologi Universitas Pembangunan Jaya, Catatan Proses Workshop Atlet Jaya Raya, tidak dipublikasikan, 2017.

14. Program Studi Psikologi Universitas Pembangunan Jaya, Transkripsi Focus Group Discussion di Kediaman Ir. Ciputra, tidak dipublikasikan, 2016.

15. Program Studi Psikologi Universitas Pembangunan Jaya, Transkripsi Focus Group Discussion dengan Pelatih Fisik, Pelatih Teknik, Guru dan Pengurus Asrama, tidak dipublikasikan, 2017.
16. Program Studi Psikologi Universitas Pembangunan Jaya, Transkripsi Wawancara Amran Siregar, tidak dipublikasikan, 2017.

17. Program Studi Psikologi Universitas Pembangunan Jaya, Transkripsi Wawancara Ardanti Ratna Widyastuti, tidak dipublikasikan, 2017.

18. Program Studi Psikologi Universitas Pembangunan Jaya, Transkripsi Wawancara Danu Hoedaya, tidak dipublikasikan, 2017.

19. Program Studi Psikologi Universitas Pembangunan Jaya, Transkripsi Wawancara Lilik Sudarwati, tidak dipublikasikan, 2017.

20. Program Studi Psikologi Universitas Pembangunan Jaya, Transkripsi Wawancara Yusuf Hidayat, tidak dipublikasikan, 2017.

21. Putri, D., Gambaran Penerapan Managing Anxiety pada Atlet Tunggal Taruna di Klub Bulutangkis "XYZ" Skripsi Universitas Pembangunan Jaya, 2016.

22. Rana, M.S., Assessment of Physiological Variables of Bulutangkis Players, International Journal of Behavioral Social and Movement Sciences Vol. 01, Issue 04, Oct., 2012.

23. Sleezer, C.M., Russ-Eft, D.F. \& Gupta, K., A Practical Guide to Needs Assessment Edisi ke-3 New York: Wiley, 2014.

24. Tempo, Menang Telak, PB Jaya Raya Juara Pembangunan Jaya Cup, Diakses dari https://m.tempo.co/read/news/2016/12 /17/100828650/menang-telak-pb-jayaraya-juara-pembangunan-jaya-cup tanggal 31 Januari 2017.

25. Williams, J.M. \& Straub, W.F., Sport Psychology: Past, Present, Future New York: McGraw-Hill, 2010.

26. Wondowisnowo, B.H., 40 tahun $P B$ Jaya Raya Tak Pernah Henti Lahirkan Juara, Jakarta: Yayasan Pembangunan Jaya Raya, 2016. 